\title{
Loss of KCNQ1 expression in stage II and stage III colon cancer is a strong prognostic factor for disease recurrence
}

Sjoerd H den Uil ${ }^{1,2}$, Veerle M H Coupé ${ }^{3}$, Janneke F Linnekamp ${ }^{4}$, Evert van den Broek ${ }^{1,5}$, Jeroen A C M Goos ${ }^{1}$, Pien M Delis-van Diemen ${ }^{1,5}$, Eric J Th Belt ${ }^{6}$, Nicole C T van Grieken ${ }^{1}$, Patricia M Scott ${ }^{7}$, Louis Vermeulen ${ }^{4}$, Jan Paul Medema ${ }^{4}$, Herman Bril ${ }^{8}$, Hein B A C Stockmann ${ }^{2}$, Robert T Cormier ${ }^{7}$, Gerrit A Meijer ${ }^{1,5}$ and Remond J A Fijneman*,1,5

${ }^{1}$ Department of Pathology, VU University Medical Center, Amsterdam 1081HV, The Netherlands; ${ }^{2}$ Department of Surgery, Spaarne Gasthuis, Haarlem 2035RC, The Netherlands; ${ }^{3}$ Department of Epidemiology and Biostatistics, VU University Medical Center, Amsterdam 1081HV, The Netherlands; ${ }^{4}$ Laboratory of Experimental Oncology and Radiobiology, Center for Experimental Molecular Medicine, Academic Medical Center, Amsterdam 1100DD, The Netherlands; ${ }^{5}$ Department of Pathology, The Netherlands Cancer Institute, Amsterdam 1066CX, The Netherlands; ${ }^{6}$ Department of Surgery, Albert Schweitzer Hospital, Dordrecht 3300AK, The Netherlands; 'Department of Biomedical Sciences, University of Minnesota Medical School, Duluth, Minnesota, MN 55812, USA and ${ }^{8}$ Department of Pathology, Spaarne Gasthuis, Haarlem 2035RC, The Netherlands

Background: Colorectal cancer (CRC) is the third most common cancer worldwide. Accurately identifying stage II CRC patients at risk for recurrence is an unmet clinical need. KCNQ1 was previously identified as a tumour suppressor gene and loss of expression was associated with poor survival in patients with CRC liver metastases. In this study the prognostic value of KCNQ1 in stage II and stage III colon cancer patients was examined.

Methods: KCNQ1 mRNA expression was assessed in 90 stage II colon cancer patients (AMC-AJCCII-90) using microarray gene expression data. Subsequently, KCNQ1 protein expression was evaluated in an independent cohort of 386 stage II and stage III colon cancer patients by immunohistochemistry of tissue microarrays.

Results: Low KCNQ1 mRNA expression in stage II microsatellite stable (MSS) colon cancers was associated with poor disease-free survival (DFS) $(P=0.025)$. Loss of KCNQ1 protein expression from epithelial cells was strongly associated with poor DFS in stage II MSS $(P<0.0001)$, stage III MSS $(P=0.0001)$ and stage III microsatellite instable colon cancers $(P=0.041)$ KCNQ1 seemed an independent prognostic value in addition to other high-risk parameters like angio-invasion, nodal stage and microsatellite instability-status.

Conclusions: We conclude that KCNQ1 is a promising biomarker for prediction of disease recurrence and may aid stratification of patients with stage II MSS colon cancer for adjuvant chemotherapy.

With over 1.3 million new patients a year and an estimated 694000 deaths in 2012, colorectal cancer (CRC) is an increasing healthcare issue, especially in more developed countries (Ferlay et al, 2015). Current guidelines for treatment of primary non-metastatic colon cancer prescribe surgery and adjuvant systemic therapy, the latter based on pathological staging and clinical features. There is consensus that adjuvant chemotherapy generally improves survival in stage III CRC patients without significant comorbidities

*Correspondence: Dr RJA Fijneman; E-mail: r.fijneman@nki.nl

Received 29 June 2016; revised 29 September 2016; accepted 17 October 2016; published online 17 November 2016

(c) 2016 Cancer Research UK. All rights reserved 0007 - 0920/16 
(Moertel et al, 1990; Andre et al, 2009; Haller et al, 2011). For stage II CRC patients this is less obvious and only patients with high-risk features may benefit from adjuvant treatment (Benson et al, 2004; Figueredo et al, 2008; Yothers et al, 2011). However, the definition of these high-risk features remains subject of debate. The high-risk clinicopathological features as defined by ASCO-guidelines are perforation or obstruction at presentation, T4, no or poorly differentiated, vascular invasion or inadequate amount of harvested lymph nodes (Benson et al, 2004). With 5-year survival rates ranging from 72 to $83 \%$ for stage II and $44-83 \%$ for stage III CRC patients, $\sim 25 \%$ of stage II CRC patients who do not receive chemotherapy will have disease recurrence. Furthermore a substantial proportion of stage III patients suffers from the side effects of chemotherapy although they might not develop recurrences even if they would not receive adjuvant therapy (O'Connell et al, 2004). Therefore there is a clear clinical need for better prognostic markers to more accurately identify stage II patients at high-risk and stage III patients at low risk of disease recurrence.

Clinical disease course is driven by tumour biology and biomarkers therefore have the potential to complement and improve prognostic value of current clinicopathological features. One example of such a biomarker is microsatellite instability (MSI), which is associated with a more favourable prognosis in stages I and II disease compared with microsatellite stable (MSS) tumours (Sinicrope et al, 2006; Vilar and Gruber, 2010; Sinicrope and Sargent, 2012; de Cuba et al, 2015). Within the group of MSS patients, which comprises $80-85 \%$ of all CRCs, there are still major differences in survival, so further stratification is needed for adequate selection of patients who may benefit from adjuvant chemotherapy. Recently, several studies succeeded to classify CRC patients into subgroups with relatively good or poor prognosis, in particular based on RNA signatures (Schlicker et al, 2012; Budinska et al, 2013; De Sousa E Melo et al, 2013; Marisa et al, 2013; Sadanandam et al, 2013; Roepman et al, 2014; Guinney et al, 2015). However, clinical implementation of such gene signatures faces practical hurdles because collection and processing of freshfrozen tumour samples for RNA isolation is not an established routine workflow in most hospitals, and is logistically demanding. One solution to this problem is to identify prognostic biomarkers that can be implemented in existing routine clinical workflows, such as protein biomarkers that can be evaluated by immunohistochemical staining of formalin-fixed paraffin-embedded (FFPE) tissue material.

We previously identified KCNQ1 as a tumour suppressor gene in mouse and human gastrointestinal cancers (Than et al, 2014). The KCNQ1 gene is located on chromosome 11p15.5 and encodes for the $\alpha$-subunit of voltage-gated potassium channels. KCNQ1 has mainly been studied for its function in the basolateral cell membrane and its predominant presence in cardiac tissue (Peroz et al, 2008), but recently its role in tumourigenesis has gained interest (Starr et al, 2009; March et al, 2011; Than et al, 2014). It was postulated that Kcnq1 mutations have a role in the development of metaplasia, dysplasia and pre-malignant adenomatous hyperplasia and gastric cancer (Elso et al, 2004). In CRC, Kcnq1 ranked among the highest common insertion site genes in several sleeping beauty DNA-transposon-based forward genetic screens, indicating its putative role as a cancer-driver gene (Starr et al, 2009; March et al, 2011; Takeda et al, 2015). This was further confirmed by studies of Kcnq1 knockout mice, which exhibited enhanced intestinal tumour multiplicity and tumour progression. Moreover, loss of KCNQ1 expression in human CRC liver metastases was associated with poor prognosis (Than et al, 2014). Interestingly, $\beta$-catenin has been described to regulate KCNQ1 protein expression in cardiac and gastric tissue (Rotte et al, 2009; Wilmes et al, 2012). Indeed, activation of the Wnt signalling pathway in vivo by conditional deletion of $A P C$, in which $\beta$-catenin has a crucial role, resulted in increased expression of well-known Wnt-target genes such as CD44 as well as increased expression of KCNQ1 (Sansom et al, 2004).

So far, the role of KCNQ1 in colon cancer patients who lack distant metastases has not been established. Therefore, the present study aimed to determine the prognostic value of KCNQ1 in stages II and III colon cancer patients. We here report that loss of KCNQ1 protein expression is a strong prognostic factor for recurrence and survival in stages II and III colon cancer patients.

\section{MATERIALS AND METHODS}

Patient study populations. The present study made use of two previously published patient series to examine associations of KCNQ1 to disease-free survival (DFS). The AMC-AJCCII-90 series consisted of 90 stage II colon cancer patients from the Academic Medical Center in Amsterdam, the Netherlands (De Sousa E Melo et al, 2013), and was used to investigate association of KCNQ1 mRNA expression to DFS. The second series consisted of 226 stage II and 160 stage III colon cancer patients from the Kennemer Gasthuis in Haarlem, the Netherlands (Belt et al, 2011b), and was used to investigate the relation between KCNQ1 protein expression and DFS. All CRC cases were sporadic except for one patient with Lynch syndrome (HNPCC) and one patient with familial adenomatous polyposis in the AMC-cohort. Both study populations have previously been characterised for MSI status by a fivemarker-based PCR analysis system, as described previously (Belt et al, 2012; De Sousa E Melo et al, 2013). Collection, storage and use of clinicopathological data and tissue specimens were performed in compliance with the 'Code for Proper Secondary Use of Human Tissue in The Netherlands' (The Code for Proper Secondary Use of Human Tissue (2011)).

KCNQ1 mRNA expression analysis. The AMC-AJCCII-90 cohort was previously characterised for genome-wide gene expression by microarray analysis (GSE33113) (De Sousa E Melo et al, 2013). For the present study, KCNQ1 mRNA expression in tumour tissue was dichotomised in low and high expression using a cutoff that was determined based on optimal separation (R2 platform, http://hgserver1.amc.nl/). Hazard ratios (HR), 95\% confidence intervals $(95 \% \mathrm{CI})$ and $P$-values were calculated using Cox regression analysis. DFS survival curves were visualised by Kaplan-Meier curves and compared using the log-rank test.

KCNQ1, $\beta$-catenin and CD44 protein expression analysis. The Kennemer Gasthuis series of 386 stages II and III colon cancers was previously used to generate tissue microarrays (TMAs) (Belt et al, 2011b). In brief, three core biopsies (diameter $0.6 \mathrm{~mm}$ ) were obtained from the centre and three from the periphery of each FFPE tumour tissue donor block and inserted into recipient TMA paraffin blocks using the 3DHISTECH TMA Master (v1.14, 3DHISTECH Ltd, Budapest, Hungary). Protein expression was evaluated by immunohistochemical staining of TMAs.

Sections, $4 \mu \mathrm{m}$ thick, were mounted on glass slides, deparaffinised by xylene and rehydrated with a decreasing alcohol series. Staining for KCNQ1 was performed following antigen retrieval by microwave heating in citric acid (10 mM, pH 6.0) and endogenous peroxidase neutralisation in $0.3 \%$ hydrogen peroxide in methanol for $25 \mathrm{~min}$, as described previously (Than et al, 2014). The primary rabbit polyclonal antibody directed against human KCNQ1 (sc-20816; Santa Cruz Biotechnology Inc., Santa Cruz, CA, USA) was incubated overnight at a $1: 200$ dilution at $4{ }^{\circ} \mathrm{C}$, followed by incubation with anti-rabbit secondary antibodies for $30 \mathrm{~min}$ at room temperature (Envision Plus; Dako, Heverlee, Belgium). Secondary antibodies were visualised by liquid diaminobenzidine substrate chromogen system. Slides were counterstained with Mayer's hematoxylin. FFPE colon tissue was used as positive 
control whereas incubation without primary antibody was used as negative control. Staining for $\beta$-catenin (CTNNB1) was performed upon antigen retrieval by microwave heating in Tris buffer $(\mathrm{pH}$ 9.0) and endogenous peroxidase neutralisation in $0.3 \%$ hydrogen peroxide in methanol for $25 \mathrm{~min}$, followed by incubation with a mouse monoclonal antibody directed against human $\beta$-catenin (NCL-B-CAT, clone $17 \mathrm{c} 2$, Menarini, Florence, Italy) in a $1: 100$ dilution for $1 \mathrm{~h}$ at room temperature. Staining for CD44 was performed upon antigen retrieval by microwave heating in citric acid $(\mathrm{pH}$ 6.0) and endogenous peroxidase neutralisation in $0.3 \%$ hydrogen peroxide in methanol for $25 \mathrm{~min}$, followed by incubation with a monospecific polyclonal rabbit antibody was used (HPA005785, Atlas antibodies, Stockholm, Sweden) in a $1: 150$ dilution for one hour at room temperature. $\beta$-catenin and CD44 antibody binding was detected using Brightvision + (Lot.no 80430J, Immunologic, Duiven, The Netherlands).

Immunohistochemical stainings were digitally captured using the Mirax slide scanner system equipped with a $\times 20$ objective with a numerical aperture of 0.75 (Carl Zeiss BV, Sliedrecht, The Netherlands) and a Sony DFW-X710 Fire Wire 1/3 in-type progressive SCAN IT CCD (pixel size $4.65 \times 4.65 \mu \mathrm{m}^{2}$ ). Actual scan resolution at $\times 20$ was $0.23 \mu \mathrm{m}$, as described previously (Belt et al, 2011b). TMA core biopsies were scored for neoplastic epithelial cell membrane staining intensity of KCNQ1 and CD44, and nuclear staining intensity of $\beta$-catenin (categories negative, weak, moderate and strong), using dedicated TMA scoring software (v.1.14.25.1; 3DHISTECH Ltd). Damaged and missing cores, defined as less than one-third of core remaining, were not scored. Highest scores on intensity for each patient were converted to a clinical SPSS (IBM SPSS Statistics, SPSS Inc., v.20.0 for windows, Chicago, IL, USA) database. Since no differences were observed between tumour central and peripheral locations for KCNQ1, CD44 and $\beta$-catenin, these cores were combined for further analysis. In this way, 377 patients could be assessed for KCNQ1 staining, 372 patients for CD44 staining and 378 patients for $\beta$-catenin staining.

Protein expression scores for KCNQ1, $\beta$-catenin and CD44 were dichotomised for analysis of patient subgroups. First, the data was randomly split into five subsets. Next, the optimal cutoff for dichotomising scores into a high- or low-expression group was based on four-fifth of the data set using receiver operating characteristic curve analysis for survival data with 5-year DFS as the outcome of interest. This procedure was repeated five times, with one-fifth of the data set varying. The final cutoff was the cutoff that was most often selected. In this way, the optimal cutoff for KCNQ1 was set to 'low expression' for negative and weak intensity scores and 'high expression' for moderate and strongintensity scores. The optimal cutoff for $\beta$-catenin was set to 'low expression' for negative and 'high expression' for weak, moderate and strong-intensity scores. For CD44 the optimal cutoff was set to 'low expression' for negative, weak and moderate intensity scores and 'high expression' for strong-intensity scores.

Statistical evaluation. Differences in baseline characteristics between the groups with high and low expression of KCNQ1 were analysed using the independent $t$-test in case of continuous variables, taking Levene's test for equality of variances into account. The Pearson's $\chi^{2}$-test (or Fisher's exact test when appropriate) was used to examine associations between dichotomous or categorical variables. $\mathrm{HR}, 95 \% \mathrm{CI}$, and $P$-values were calculated using Cox regression analysis. High expression was used as the reference category for each of the three biomarkers. Diseasefree survival was visualised by Kaplan-Meier curves and compared using the log-rank test. Multivariate analysis was performed using stepwise backwards Cox regression, with DFS as dependent variable and an exclusion criterion of $P>0.1$. Based on the 'rule of 10 ' only a limited number of variables were allowed comprising KCNQ1 and 11 other parameters including previously identified prognostic variables. These parameters were tumour location (right-sided), $\mathrm{T}$ - and $\mathrm{N}$-stage, stage, isolated tumour deposits, angio-invasion, grade of differentiation, ulceration, perforation, tumour spill and MSI status (Benson et al, 2004; Belt et al, 2010; Sinicrope and Sargent, 2012; Park et al, 2015). Associations between expression of KCNQ1 and $\beta$-catenin or CD44 expression were analysed with the $\chi^{2}$-test. All statistical tests were two-sided. $P$-values $<0.05$ were considered significant. Analyses were performed using SPSS.

\section{RESULTS}

Low KCNQ1 mRNA expression is associated with poor DFS in stage II MSS colon cancer patients. To investigate prognostic value of KCNQ1 mRNA expression in non-metastatic CRC patients, we made use of existing gene expression data from the AMC-AJCCII-90 study population consisting of 90 stage II colon cancer patients (De Sousa E Melo et al, 2013). Overall, no significant association between KCNQ1 mRNA expression levels and DFS was observed (Figure 1A). Because MSI status is a known confounding factor with prognostic value in stage II CRC patients, (Vilar and Gruber, 2010; Sinicrope and Sargent, 2012) the association between KCNQ1 mRNA expression and DFS was analysed in MSS $(n=65)$ and MSI tumours $(n=25)$ separately. Low expression of KCNQ1 was associated with poor survival in patients with stage II MSS tumours (HR 3.35, 95\% CI 1.16-9.66, $P=0.025$; Figure 1B) but not in patients with MSI tumours (HR 0.24 ; $95 \%$ CI $0.03-2.15 ; P=0.20$; Figure $1 C$ ). These mRNA data indicate that KCNQ1 has prognostic potential in non-metastatic
A

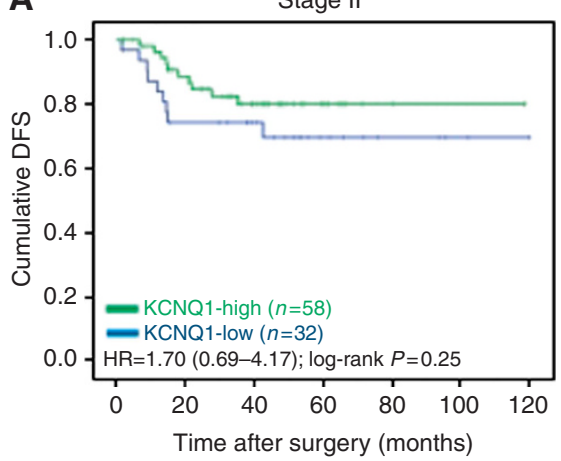

B

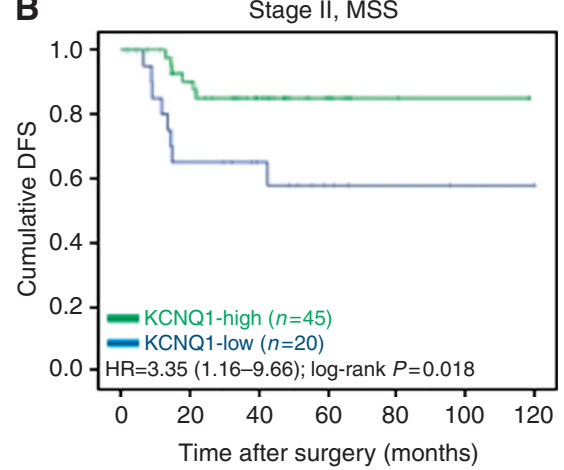

C

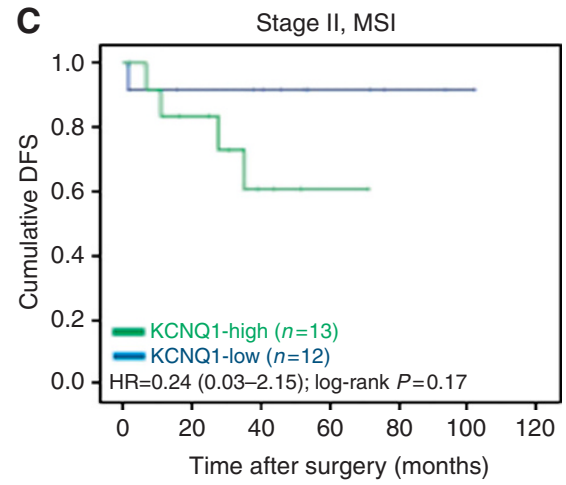

Figure 1. Association of KCNQ1 mRNA expression with DFS of (A) stage II colon cancer patients (AMC-AJCCII-90 study population); (B) the subset of MSS patients; and (C) the subset of MSI patients. Cox regression HR $(95 \% \mathrm{Cl})$ and log-rank $P$-values are reported. 
CRC, and prompted us to further validate these findings. Because determination of protein expression by immunohistochemistry is part of existing clinical workflows, loss of KCNQ1 protein expression in neoplastic epithelial cells was analysed subsequently.

Loss of KCNQ1 expression is associated with poor DFS in stage II/III MSS and stage III MSI colon cancer patients. Prognostic value of KCNQ1 protein expression by neoplastic cells was examined by immunohistochemical evaluation of TMAs containing tumour tissue from 226 stage II and 160 stage III colon cancer patients (Figure 2A-D). Association between KCNQ1 staining intensity and DFS is clearly demonstrated in Figure 2E. This figure shows that decreasing amounts of epithelial KCNQ1 expression were associated with increasingly worse prognosis. To analyse the effects of KCNQ1 in subgroups of colon cancer patients, protein expression data were dichotomised into 'low' and 'high' KCNQ1 expression. Low KCNQ1 expression was associated with poor DFS in stage II colon cancer patients (HR 3.61; 95\% CI 2.07-6.33; $P<0.0001$; Figure $3 \mathrm{~A}$ ) and in stage III colon cancer patients (HR 3.11; 95\% CI1.93-5.01; $P=0.0001$; Figure 3D). Because MSI status is a known confounding factor (Vilar and Gruber, 2010; Sinicrope and Sargent, 2012), the prognostic value of KCNQ1 expression was also analysed in stage II and III MSS and MSI patients separately. MSI status had previously been determined for 325 patients of this cohort, revealing 63 MSI (19\%) and 262 MSS (81\%) colon tumours (Belt et al, 2012). In the group of MSS tumours, low expression of KCNQ1 was associated with poor DFS in both stage II colon cancer patients (HR 3.82; 95\% CI 2.04-7.14; $P<0.0001$; Figure 3B) and stage III colon cancer patients (HR 2.93; 95\% CI 1.70-5.02; $P<0.0001$; Figure 3E). In the group of MSI tumours, low expression of KCNQ1 was not significantly associated with DFS in stage II colon cancer patients (HR 3.37; 95\% CI 0.38-30.17; $P=0.278$; Figure $3 \mathrm{C}$ ), but was associated with poor DFS in stage III colon cancer patients (HR 5.06; 95\% CI 1.07-23.89; $P=0.041$; Figure $3 \mathrm{~F}$ ). Interestingly, MSI tumours exhibited significantly more frequently loss of KCNQ1 expression than MSS tumours $(P=0.001)$. These and other baseline characteristics of this cohort are presented in Table 1.

Loss of KCNQ1 expression is associated with poor DFS in stage III MSS colon cancer patients stratified for adjuvant chemotherapy. A large subset of patients had been treated with 5FU-based adjuvant chemotherapy, which is likely to affect survival. Therefore the association between KCNQ1 expression and DFS was analysed separately in subgroups of stages II and III patients who did or did not receive adjuvant chemotherapy. Only MSS patients were analysed, because the number of MSI patients was too small for further analysis of patient subgroups. In patients who did not receive chemotherapy, low expression of KCNQ1 was associated with poor DFS in stage II patients (HR 4.06; 95\% CI 2.04-8.09; $P<0.0001$; Figure 4A) and stage III patients (HR 3.01; 95\% CI $1.25-7.22 ; P=0.014$; Figure $4 \mathrm{C}$ ). In patients who did receive chemotherapy, low expression of KCNQ1 was associated with poor DFS in stage III patients (HR 2.88; 95\% CI 1.44-5.77; $P=0.002$; Figure 4D). No association was observed between KCNQ1 expression and stage II patients who received adjuvant therapy (Figure 4B); however, it should be noted that this subgroup of patients was relatively small $(n=24)$. Collectively, these data indicate that loss of KCNQ1 expression is a strong prognostic biomarker to identify stages II and III colon cancer patients at high-risk for disease recurrence, irrespective of adjuvant chemotherapy.

Loss of KCNQ1 is an independent prognostic factor in stages II and III colon cancer. To analyse the added value of KCNQ1 protein expression to current clinicopathological parameters, a multivariate model for 5-year DFS was built using stepwise backward Cox-regression. The variables 'isolated tumour deposits', 'nodal stage', 'angio-invasion' and 'MSI status' were retained in the model, in addition to KCNQ1 expression (Table 2). These data demonstrate that loss of KCNQ1 expression is a strong predictor for poor DFS in the entire study population, with added value to established clinicopathological factors (HR 3.75; 95\% CI 2.50-5.64; $P<0.0001$, Table 2).

KCNQ1 expression is correlated to expression of $\beta$-catenin and CD44. It has been postulated that expression of KCNQ1 is regulated by $\beta$-catenin and as such results from activation of the Wnt signalling pathway (Sansom et al, 2004; Rotte et al, 2009; Wilmes et al, 2012). TMA's were stained for $\beta$-catenin and the Wnt-target gene CD44. Dichotomised expression was used to investigate whether KCNQ1 expression was correlated to active Wnt signalling. Indeed, KCNQ1 expression was significantly correlated to expression of $\beta$-catenin and CD44 in MSS colon
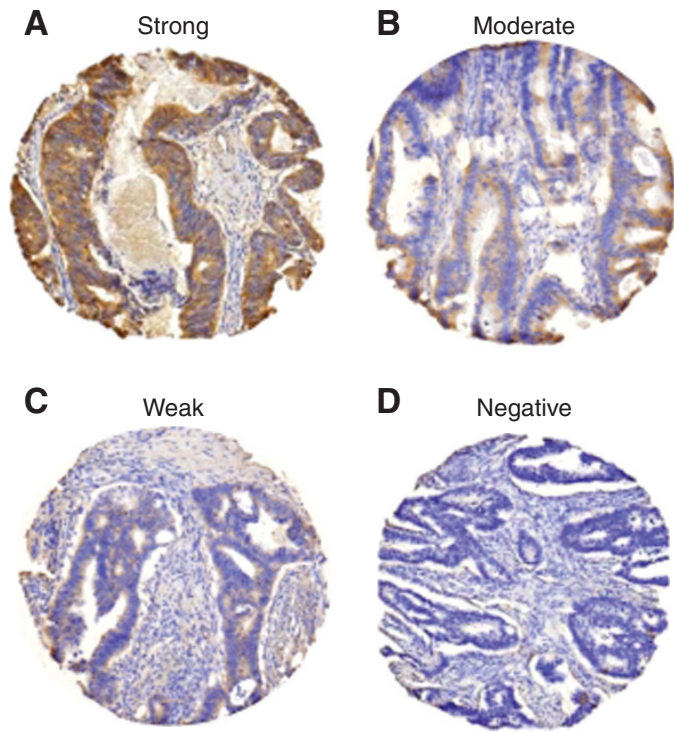

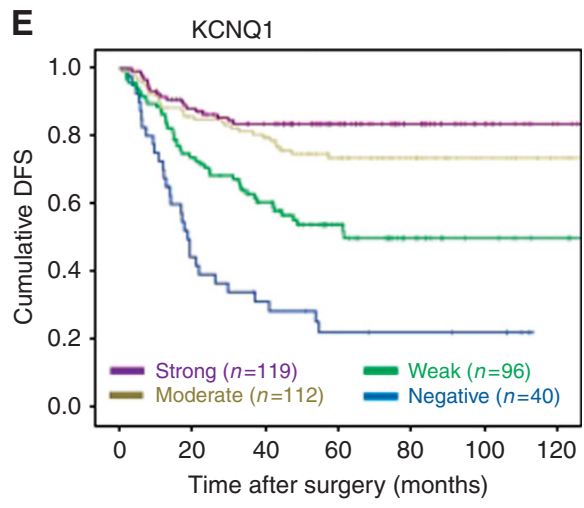

Figure 2. KCNQ1 protein expression and its association with DFS of stages II and III colon cancer patients. (A-D) Representative examples ((A) strong, (B) moderate, (C) weak and (D) negative) of immunohistochemical staining intensities of KCNQ1 expression. (E) Association of KCNQ1 protein expression levels with DFS. 
A
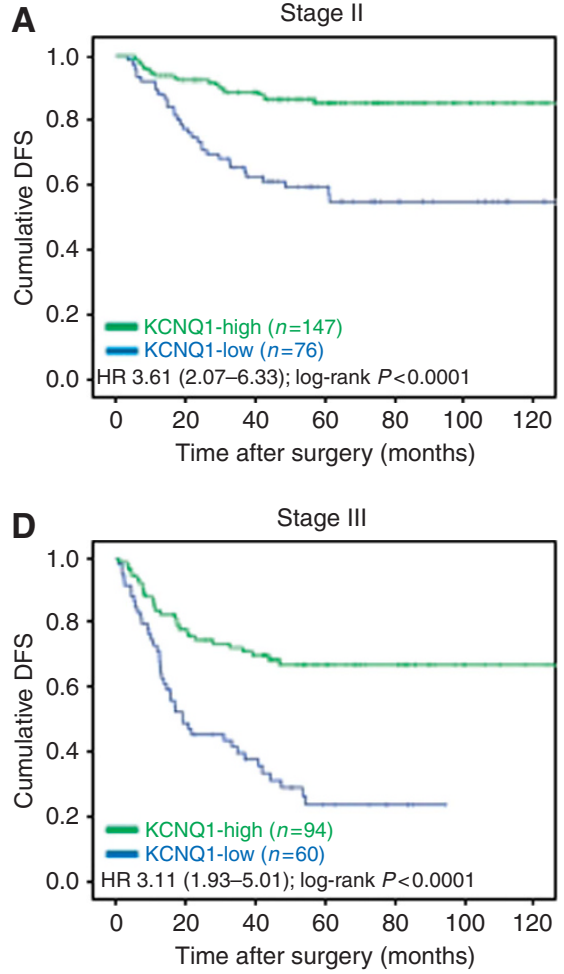

B

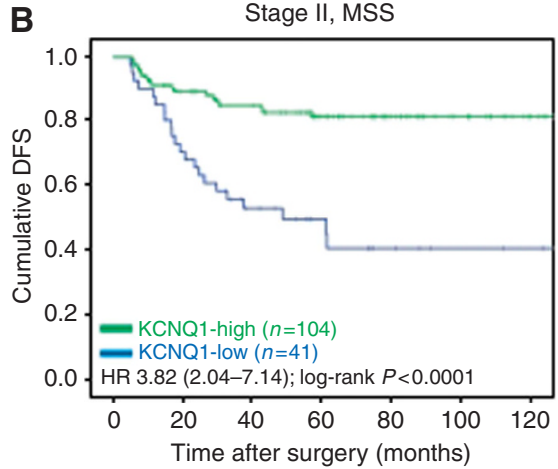

E

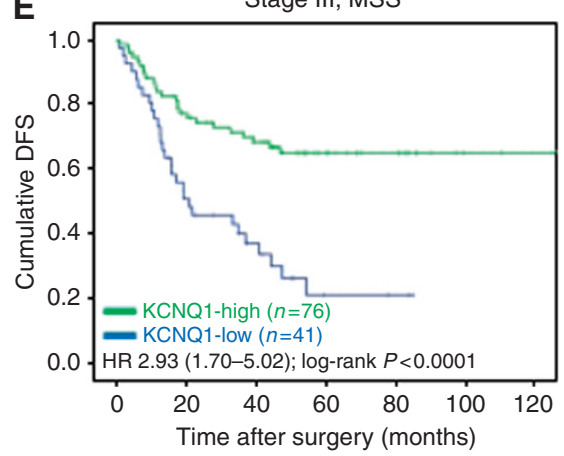

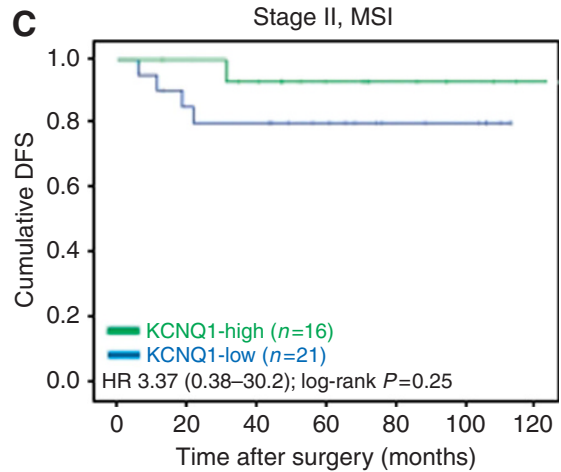

C

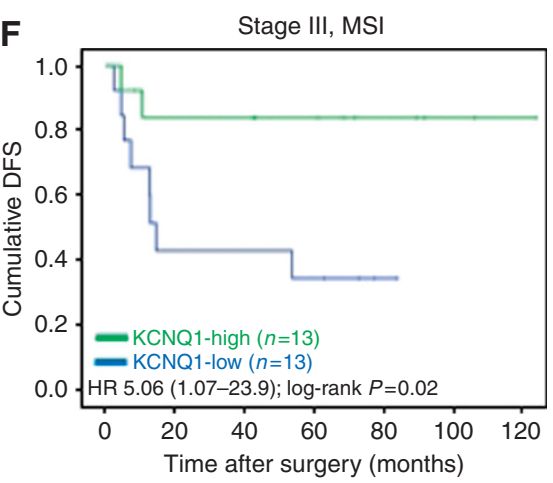

Figure 3. DFS for stage II (A-C) and III (D-F) colon cancer patients, stratified for high- and low-expression of KCNQ1 in all patients (A and D), the subset of MSS patients ( $\mathbf{B}$ and $\mathbf{E}$ ) and the subset of MSI patients ( $\mathbf{C}$ and $\mathbf{F}$ ). Cox regression $\mathrm{HR}(95 \% \mathrm{Cl})$ and log-rank $P$-values are reported.

cancers $\left(\chi^{2}\right.$-test $P=0.003$ and $P=0.001$, respectively), but not in MSI colon cancers $(P=0.076$ and $P=0.12$, respectively). Despite these significant correlations, expression of nuclear $\beta$-catenin was not significantly associated with DFS (HR 0.83; 95\% CI 0.58-1.21; $P=0.33$; Figure $5 \mathrm{~A})$. In contrast, low expression of CD44 was associated with poor DFS (HR 2.77; 95\% CI 1.35-5.68; $P=0.005$; Figure 5B). However, the association of CD44 with DFS was less strong than that of KCNQ1, and was lost upon further analyses of subgroups of colon cancer patients based on stage, MSI status or adjuvant treatment.

\section{DISCUSSION}

The present study addressed the prognostic value of KCNQ1 expression in stages II and III colon cancer patients. We here demonstrate that loss of expression of KCNQ1 in epithelial cells is strongly associated with a high risk for disease recurrence, and has additional prognostic value to clinicopathological features that are currently used to select high-risk stage II patients such as angioinvasion, nodal stage and MSI status. These findings are in line with our previous observation that KCNQ1 expression in CRC liver metastases was associated with poor overall survival (Than et al, 2014). Importantly, the prognostic value of KCNQ1 was clearly apparent in both stages II and III MSS colon cancers. In stage III tumours, its prognostic value was evident irrespective of treatment with adjuvant chemotherapy. Moreover, the prognostic value of KCNQ1 was also demonstrated in the smaller subgroup stage III MSI cancers. Only for stage II MSI tumours no significant association was observed between KCNQ1 and DFS, probably due to the limited number of patients in this subgroup combined with the fact that these patients have a relatively good prognosis (Vilar and Gruber, 2010; Sinicrope and Sargent, 2012). Taken together, these data show that loss of KCNQ1 expression from neoplastic epithelial cells is a biomarker that strongly predicts disease recurrence and poor survival in stages II and III colon cancer.

At present, the most promising prognostic biomarkers for stage II colon cancer are based on mRNA signatures (Schlicker et al, 2012; Budinska et al, 2013; De Sousa E Melo et al, 2013; Marisa et al, 2013; Sadanandam et al, 2013; Roepman et al, 2014; Guinney et al, 2015). Making use of the external AMC-AJCCII-90 cohort from which one of these mRNA signatures was derived (De Sousa E Melo et al, 2013), we showed that low KCNQ1 mRNA levels were associated with poor prognosis of stage II MSS patients. Protein expression of KCNQ1 was analysed in a second and independent cohort, which confirmed its prognostic value and demonstrated an even stronger association with DFS. Differences between KCNQ1 mRNA and protein analysis may be due to the fact that mRNA levels are determined on tissue lysates, which include cells from both neoplastic epithelial origin as well as non-neoplastic cells in the tumour stromal compartments. In contrast, KCNQ1 protein analysis was focused on expression in neoplastic epithelial cells only, and its score is therefore not affected by variation in tumour stromal content. The hazard rate ratio for KCNQ1 protein expression in the present study (HR $>3.5$ for stage II and HR $>4.0$ for stage II MSS patients) was higher than that of biomarkers that have been identified previously using this study population, such as lamin A/C, AURKA, versican, lumican, BclXL, FAS, Bcl-2 and FasL (Belt et al, 2011a; Belt et al, 2011b; de Wit et al, 2013; Belt et al, 2014). Only MGL ligand has been identified as a biomarker with comparatively strong effects in this study population, albeit restricted to the subgroup of stage III colon cancers (Lenos et al, 2015). Interestingly, the prognostic value of KCNQ1 protein expression in stage II CRC patients in the present study is comparable to or better than the HRs reported for validated gene expression signatures like OncotypeDX Colon Cancer (HR's ranging from 1.38 to 1.96 (Gray et al, 2011; Venook et al, 2013; Yothers et al, 2013)), ColoPrint (HR's ranging from 2.16 to 2.65 (Salazar et al, 2011; Maak et al, 2013; 
Table 1. Clinicopathological characteristics of 377 colon cancer patients, stratified for low and high KCNQ1 protein expression

\begin{tabular}{|c|c|c|c|c|}
\hline Clinicopathological characteristics & Total: $\mathbf{n}=\mathbf{3 7 7}(\%)$ & KCNQ1-low: $n=136(\%)$ & KCNQ1-high: $n=241(\%)$ & $P$-value \\
\hline $\begin{array}{l}\text { Sex } \\
\text { Male } \\
\text { Female }\end{array}$ & $\begin{array}{l}197(52.3) \\
180(47.7)\end{array}$ & $\begin{array}{l}68(50.0) \\
68(50)\end{array}$ & $\begin{array}{l}129(53.5) \\
112(46.5)\end{array}$ & 0.51 \\
\hline Right-sided tumour & $170(45.1)$ & $73(53.7)$ & $97(40.2)$ & 0.012 \\
\hline Tumour diameter, median (min-max) in $\mathrm{mm}$ & $40.0(10-130)$ & $40(12-100)$ & $35(10-130)$ & 0.09 \\
\hline $\begin{array}{l}\text { Stage } \\
\qquad \|\left(=N_{0}\right) \\
\|\|\left(=N_{+}\right)\end{array}$ & $\begin{array}{l}223(59.2) \\
154(40.8)\end{array}$ & $\begin{array}{l}76(55.9) \\
60(44.1)\end{array}$ & $\begin{array}{r}147(61.0) \\
94(39.0)\end{array}$ & 0.33 \\
\hline $\begin{array}{l}\text { Tumour stage } \\
\text { T1 } \\
\text { T2 } \\
\text { T3 } \\
\text { T4 }\end{array}$ & $\begin{array}{c}4(1.1) \\
18(4.8) \\
318(84.3) \\
37(9.8)\end{array}$ & $\begin{aligned} & 1(0.7) \\
& 5(3.7) \\
& 112(82.4) \\
& 18(13.2)\end{aligned}$ & $\begin{aligned} 3 & (1.2) \\
13 & (5.4) \\
206 & (85.5) \\
19 & (7.9)\end{aligned}$ & 0.34 \\
\hline $\begin{array}{l}\text { Nodal stage (stage III) } \\
\text { N1 } \\
\text { N2 }\end{array}$ & $\begin{array}{r}107(28.4) \\
47(12.5)\end{array}$ & $\begin{array}{l}37(27.2) \\
23(16.9)\end{array}$ & $\begin{array}{l}70(29.0) \\
24(10.0)\end{array}$ & 0.09 \\
\hline $\begin{array}{l}\text { No. of lymph nodes, mean (s.d.) } \\
\text { Positive (in stage III), mean (s.d.) }\end{array}$ & $\begin{array}{r}8.9(5.2) \\
3.39(3.3)\end{array}$ & $\begin{array}{l}8.7(5.0) \\
4.0(4.0)\end{array}$ & $\begin{array}{l}9.0(5.3) \\
3.0(2.8)\end{array}$ & $\begin{array}{l}0.57 \\
0.08\end{array}$ \\
\hline Mucinous differentiation & $80(21.2)$ & $44(32.4)$ & $36(14.9)$ & $<0.001$ \\
\hline $\begin{array}{l}\text { MSI-status } \\
\text { MSI } \\
\text { MSS } \\
\text { Unknown }\end{array}$ & $\begin{array}{r}63(16.7) \\
262(69.5) \\
52(13.8)\end{array}$ & $\begin{array}{l}34(25.0) \\
82(60.3) \\
20(14.7)\end{array}$ & $\begin{array}{r}29(12.0) \\
180(74.7) \\
32(13.3)\end{array}$ & 0.001 \\
\hline Ulceration & $290(76.9)$ & $104(76.5)$ & $186(77.2)$ & 0.88 \\
\hline Angio-invasion & $73(19.4)$ & $33(24.3)$ & $40(16.6)$ & 0.07 \\
\hline Adjuvant chemo & $122(32.6)$ & $46(33.8)$ & $76(31.5)$ & 0.65 \\
\hline Recurrence & $123(32.6)$ & $74(54.4)$ & $49(20.3)$ & $<0.001$ \\
\hline CRC mortality & $98(26.0)$ & $58(42.6)$ & $40(16.6)$ & $<0.001$ \\
\hline Overall mortality & $173(45.9)$ & $76(55.9)$ & $97(40.2)$ & 0.003 \\
\hline Follow-up, median (min-max) in months & $57.2(2.8-148.6)$ & $48.1(2.8-129.2)$ & $61.2(4.14-148.6)$ & $<0.001$ \\
\hline
\end{tabular}

Kopetz et al, 2015)), and GeneFx Colon (HR 2.53 (Kennedy et al, 2011)). Moreover, the protein staining-based KCNQ1 HRs exceed the mRNA signature-based HRs for differences between the poor survival CMS4 group and the CMS1-3 groups of colon cancers (Guinney et al, 2015), implying that KCNQ1 may have a stronger prognostic value than the consensus-based mRNA signatures. Although collection of frozen tissue for mRNA isolation is not common clinical practice, protein analysis by immunohistochemistry of FFPE material is. As such, implementation of KCNQ1 as a prognostic biomarker is technically well feasible in the current clinical setting.

Nuclear $\beta$-catenin and CD44 expression have commonly been used to indicate 'stemness' of colon cancer cells. Because $\beta$-catenin has been described to regulate KCNQ1 protein expression (Wilmes et al, 2012) and KCNQ1 expression was shown to be increased upon activation of the Wnt signalling pathway
(Sansom et al, 2004), the correlation between KCNQ1 expression and nuclear $\beta$-catenin was examined, as well as with the Wnttarget gene CD44. The current data demonstrated a positive correlation of KCNQ1 expression with both genes, and like for KCNQ1 also loss of CD44 expression was associated with poor DFS. In contrast, expression of nuclear $\beta$-catenin was not significantly associated with DFS. Therefore, while high Wntactivity is thought to lead to development and progression of cancer, our data indicate that high expression of KCNQ1 was associated with better prognosis. As such, the present findings lend further support to previous observations in which silencing of several Wnt target genes by methylation-stimulated tumour progression and was associated with poor prognosis (de Sousa E Melo et al, 2011; Silva et al, 2014). This hypothesis is further supported by the observation that loss of expression of KCNQ1 is significantly more prevalent in MSI tumours (54\%) than in MSS 

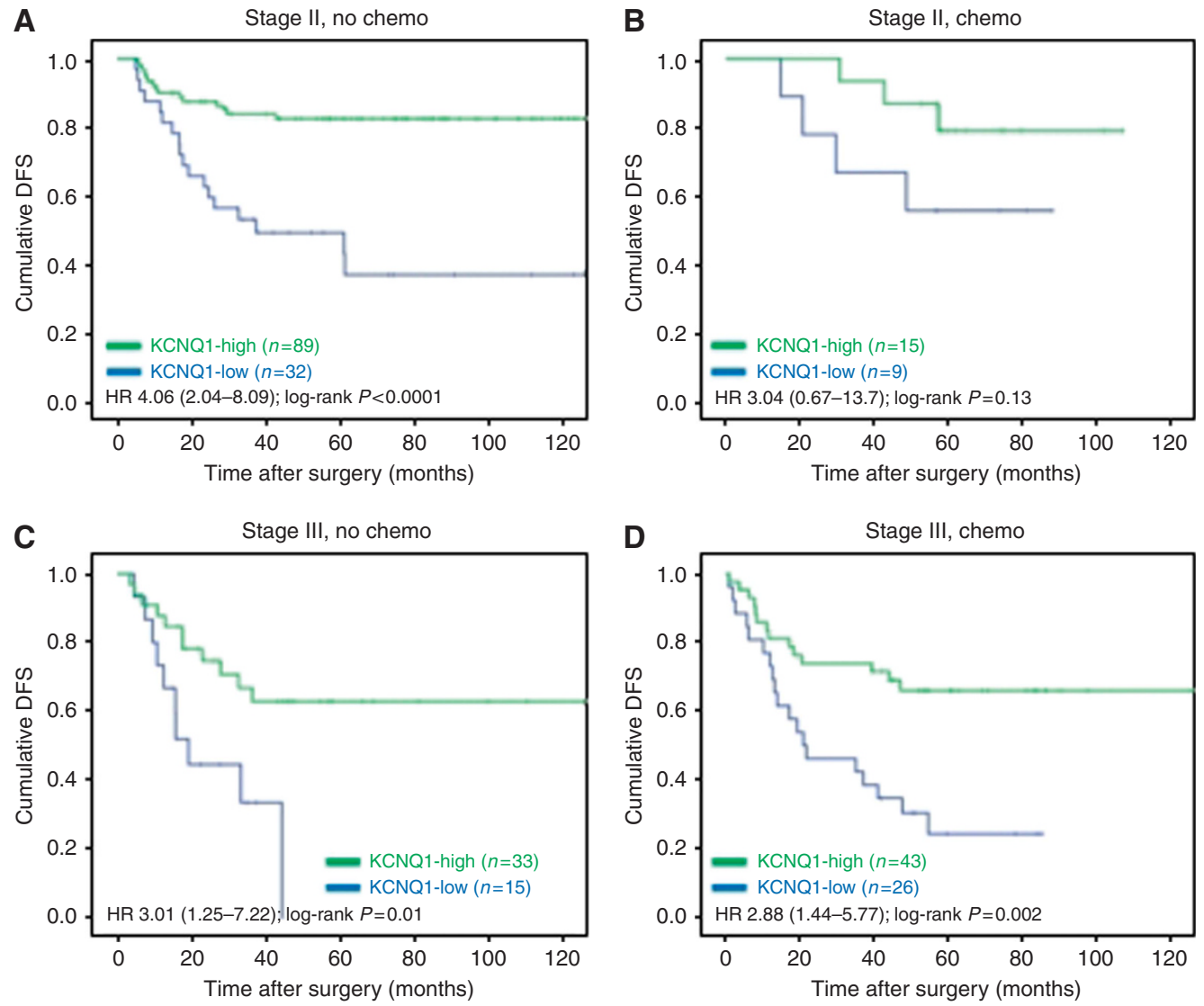

Figure 4. DFS curves for expression of KCNQ1 in MSS colon cancer patients not treated (A and $\mathbf{C})$ and treated (B and $\mathbf{D})$ with adjuvant chemotherapy for stage II (A and B) and stage III (C and D) disease. Cox regression HR (95\% Cl) and log-rank P-values are reported.

Table 2. Multivariate backward Cox-regression analysis for disease-free survival after 5 years of KCNQ1 and clinicopathological parameters that were retained in the model

\begin{tabular}{|l|c|c|c|}
\hline Parameters & HR & $\mathbf{9 5 \% - C l}$ & $\boldsymbol{P}$-value \\
\hline Isolated tumour deposits & 1.594 & $0.98-2.59$ & 0.06 \\
\hline Nodal stage & 1.683 & $1.30-2.18$ & 0.0001 \\
\hline Angio-invasion & 2.062 & $1.32-3.22$ & 0.001 \\
\hline MSI status & 0.589 & $0.34-1.03$ & 0.06 \\
\hline Low KCNQ1-expression & $\mathbf{3 . 7 5 2}$ & $\mathbf{2 . 5 0 - 5 . 6 4}$ & $<\mathbf{0 . 0 0 0 1}$ \\
\hline Abbreviations: $\mathrm{Cl}=$ confidence interval; $\mathrm{HR}=$ hazards ratio; $\mathrm{MSI}=$ microsatellite instability. \\
\hline
\end{tabular}

tumours (31\%). MSI is frequently caused by silencing of MLH1 in tumours with a CpG island methylator phenotype (Cancer Genome Atlas Network, 2012; Kim et al, 2013). These data suggest that aberrant methylation is at least one mechanism that can cause silencing of KCNQ1 expression, and show that loss of KCNQ1 expression has a prominent role in the metastatic potential of both MSS and MSI cancers. Although KCNQ1 is not included in gene panels that are used to determine the CIMP phenotype in colorectal carcinomas (Weisenberger et al, 2006), DNA hypermethylation of KCNQ1 is considered a hallmark of CIMP in renal cell cancer (Arai et al, 2014).

In the present study, MSI tumours were overrepresented among right-sided tumours, consistent with literature (Benatti et al, 2005; Buecher et al, 2013). Consequently, loss of KCNQ1 protein expression was also associated with right-sided tumours (Table 1). In multivariate analysis, however, tumour location was not retained in the model while expression of KCNQ1 and MSI-status were (Table 2).
Functionally the KCNQ1 gene encodes for a potassium channel protein. Potassium channels have an important role through their ion-channel function, with effects on proliferation, differentiation and apoptosis (Lehen'kyi et al, 2011). The active efflux of potassium changes its cellular concentrations with a subsequent passive shift of chloride regulated by CFTR, the gene affected in patients with cystic fibrosis. Transport of these ions causes the flow of water in and out of cells, thereby regulating cell volume, which is known to have direct effects on apoptotic pathways in normal cells (Pedersen et al, 2013). In this way, the function of ion channels such as KCNQ1 and CFTR can affect cell survival (Than et al, 2014, 2016). Indeed, dysfunctional ion channels and cell volume regulation have been associated with resistance to apoptosis and resistance to chemotherapy (Pedersen et al, 2013). However, the exact role of KCNQ1 amongst all $\mathrm{K}^{+}$-channel proteins in this context is not known and therefore the relation of KCNQ1 expression to apoptosis and proliferation needs further elucidation. Furthermore, we previously demonstrated that Kcnq1-deficient tissues are enriched in Cftr-deficient gene signatures as well as in Muc2-deficient signatures (Than et al, 2014). The Muc2 gene encodes for the main component of the protective mucus barrier Mucin2, which has a tumour suppressive role (Yang et al, 2008). Disruption of normal CFTR function can also lead to a diminished mucus barrier that protects intestinal epithelial cells from bacterial contact (Gustafsson et al, 2012). These data suggest that loss of KCNQ1 can lead to excessive activation of innate immune signalling that may induce cancer-promoting inflammation.

In summary, we conclude that KCNQ1 is a strong prognostic biomarker for prediction of disease recurrence in stages II and III colon cancer patients. In particular, this biomarker could be very useful to stratify patients with stage II MSS for adjuvant 

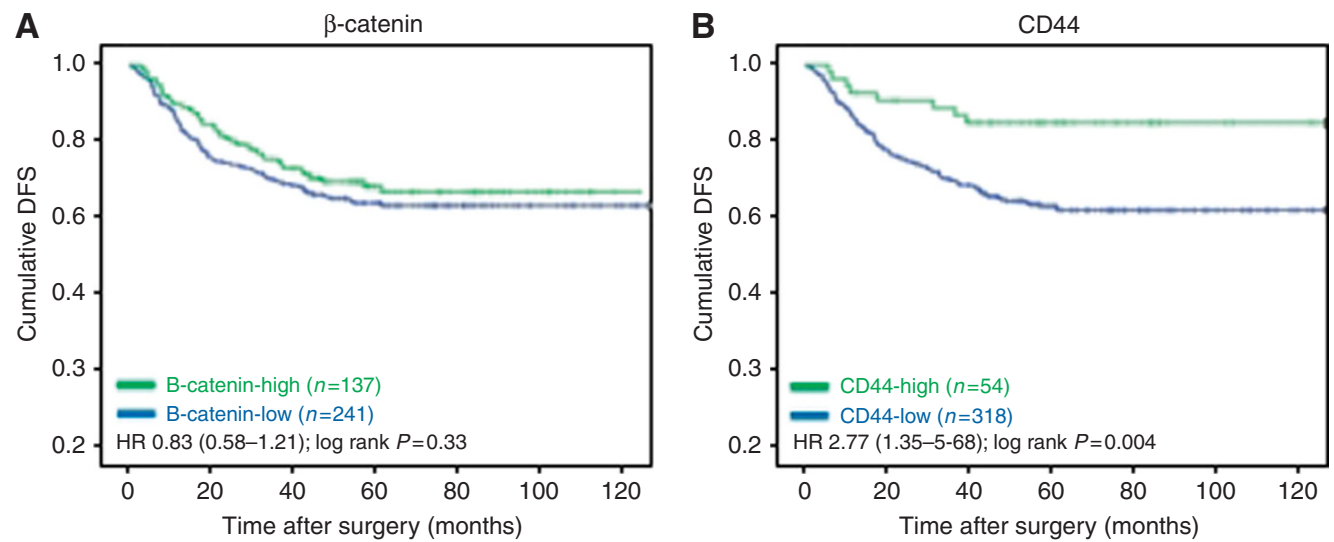

Figure 5. Association of DFS with expression of (A) nuclear $\beta$-catenin and (B) CD44. Cox regression $\mathrm{HR}(95 \% \mathrm{Cl})$ and log-rank $\mathrm{P}$-values are reported.

therapy, since selection of patients who might benefit from such treatment is still challenging. Further studies are needed both for prospective validation in a clinical setting and to address the functional role of KCNQ1 in cell homoeostasis, Wnt signalling and CRC development.

\section{ACKNOWLEDGEMENTS}

SHdU was financially supported by the 'Stichting Chirurg en Onderzoek Kennemerland' (Kennemer Gasthuis, Haarlem) and by the VUmc Cancer Center Amsterdam (project grant CCA 2011-506). PMS and RTC were supported by The National Cancer Institute (project grant R15 CA195061A-01) and The Shaver Foundation for Cancer Research and Community Fund. This work was performed within the framework of the Center for Translational Molecular Medicine, DeCoDe project (030-101) and TraIT (05T-401).

\section{CONFLICT OF INTEREST}

The authors declare no conflict of interest.

\section{REFERENCES}

Andre T, Boni C, Navarro M, Tabernero J, Hickish T, Topham C, Bonetti A, Clingan P, Bridgewater J, Rivera F, de Gramont A (2009) Improved overall survival with oxaliplatin, fluorouracil, and leucovorin as adjuvant treatment in stage II or III colon cancer in the MOSAIC trial. J Clin Oncol 27(19): 3109-3116.

Arai E, Chiku S, Mori T, Gotoh M, Nakagawa T, Fujimoto H, Kanai Y (2014) Single-CpG-resolution methylome analysis identifies clinicopathologically aggressive $\mathrm{CpG}$ island methylator phenotype clear cell renal cell carcinomas. Carcinogenesis 33(8): 1487-1493.

Belt E, Brosens R, Delis-van Diemen P, Bril H, Belien J, Stockmann H, Meijer S, Meijer G (2011a) Prognostic role of cell cycle associated proteins in stage II and III colon cancer: a large cohort multimarker study. Dis Col Rectum 54(5): E22.

Belt EJ, van Stijn MF, Bril H, de Lange-de Klerk ES, Meijer GA, Meijer S, Stockmann HB (2010) Lymph node negative colorectal cancers with isolated tumor deposits should be classified and treated as stage III. Ann Surg Oncol 17(12): 3203-3211.

Belt EJT, Fijneman RJA, van den Berg EG, Bril H, Delis-van Diemen PM, Tijssen M, van Essen HFB, de Lange-de Klerk ESM, Belien JAM, Stockmann HBA, Meijer S, Meijer GA (2011b) Loss of lamin A/C expression in stage II and III colon cancer is associated with disease recurrenece. Eur J Cancer 47(12): 1837-1845.

Belt EJT, Stockmann HBAC, Delis-van Diemen PM, Bril H, Tijssen M, van Essen HF, Heymans MW, Belien JAM, Carvalho B, Cillessen SAGM,
Meijer GA (2014) Expression of apoptosis regulating proteins identifies stage ii and iii colon cancer patients with high risk of recurrence. J Surg Oncol 109(3): 255-265.

Belt EJT, Velde EAT, Krijgsman O, Brosens RPM, Tijssen M, van Essen HF, Stockmann HBAC, Bril H, Carvalho B, Ylstra B, Bonjer HJ, Meijer GA (2012) High lymph node yield is related to microsatellite instability in colon cancer. Ann Surg Oncol 19(4): 1222-1230.

Benatti P, Gafa R, Barana D, Marino M, Scarselli A, Pedroni M, Maestri I, Guerzoni L, Roncucci L, Menigatti M, Roncari B, Maffei S, Rossi G, Ponti G, Santini A, Losi L, Di Gregorio C, Oliani C, Ponz de Leon M, Lanza G (2005) Microsatellite Instability and colorectal cancer prognosis. Clin Cancer Res 11(23): 8332-8340.

Benson 3rd AB, Schrag D, Somerfield MR, Cohen AM, Figueredo AT, Flynn PJ, Krzyzanowska MK, Maroun J, McAllister P, Van Cutsem E, Brouwers M, Charette M, Haller DG (2004) American Society of Clinical Oncology recommendations on adjuvant chemotherapy for stage II colon cancer. J Clin Oncol 22(16): 3408-3419.

Budinska E, Popovici V, Tejpar S, D’Ario G, Lapique N, Sikora KO, Di Narzo AF, Yan P, Hodgson JG, Weinrich S, Bosman F, Roth A, Delorenzi M (2013) Gene expression patterns unveil a new level of molecular heterogeneity in colorectal cancer. J Pathol 231(1): 63-76.

Buecher B, Cacheux W, Rouleau E, Dieumegard B, Mitry E, Lievre A (2013) Role of microsatellite instability in the management of colorectal cancers. Dig Liver Dis 45(6): 441-449.

Cancer Genome Atlas Network (2012) Comprehensive molecular characterization of human colon and rectal cancer. Nature 487(7407): 330-337.

de Cuba EM, Snaebjornsson P, Heideman DA, van Grieken NC, Bosch LJ, Fijneman RJ, Belt E, Bril H, Stockmann HB, Hooijberg E, Punt CJ, Koopman M, Nagtegaal ID, Coupé VH, Carvalho B, Meijer GA (2015) Prognostic value of BRAF and KRAS mutation status in stage II and III microsatellite instable colon cancers. Int J Cancer 138(5): $1139-1145$

de Sousa E Melo F, Colak S, Buikhuisen J, Koster J, Cameron K, de Jong JH, Tuynman JB, Prasetyanti PR, Fessler E, van den Bergh SP, Rodermond H, Dekker E, van der Loos CM, Pals ST, van de Vijver MJ, Versteeg R, Richel DJ, Vermeulen L, Medema JP (2011) Methylation of cancer-stem-cellassociated Wnt target genes predicts poor prognosis in colorectal cancer patients. Cell Stem Cell 9(5): 476-485.

De Sousa E Melo F, Wang X, Jansen M, Fessler E, Trinh A, de Rooij LP, de Jong JH, de Boer OJ, van LR, Bijlsma MF, Rodermond H, van der Heijden M, van Noesel CJ, Tuynman JB, Dekker E, Markowetz F, Medema JP, Vermeulen L (2013) Poor-prognosis colon cancer is defined by a molecularly distinct subtype and develops from serrated precursor lesions. Nat Med 19(5): 614-618.

de Wit M, Belt EJT, Delis-van Diemen PM, Carvalho B, Coupe VMH, Stockmann HBAC, Bril H, Belien JAM, Fijneman RJA, Meijer GA (2013) Lumican and versican are associated with good outcome in stage II and III colon cancer. Ann Surg Oncol 20: S348-S359.

Elso CM, Lu X, Culiat CT, Rutledge JC, Cacheiro NL, Generoso WM, Stubbs LJ (2004) Heightened susceptibility to chronic gastritis, hyperplasia and metaplasia in Kcnq1 mutant mice. Hum Mol Genet 13(22): 2813-2821. 
Ferlay J, Soerjomataram I, Ervik M, Dikshit R, Eser S, Mathers C, Rebelo M, Parkin DM, Forman D, Bray F (2015) Cancer incidence and mortality worldwide: sources, methods and major patterns in GLOBOCAN 2012. Int J Cancer 136(5): 359-386.

Figueredo A, Coombes ME, Mukherjee S. Adjuvant therapy for completely resected stage II colon cancer. Cochrane Database Syst Rev 2008; (3): CD005390.

Gray RG, Quirke P, Handley K, Lopatin M, Magill L, Baehner FL, Beaumont C, Clark-Langone KM, Yoshizawa CN, Lee M, Watson D, Shak S, Kerr DJ (2011) Validation study of a quantitative multigene reverse transcriptase-polymerase chain reaction assay for assessment of recurrence risk in patients with stage II colon cancer. J Clin Oncol 29(35): 4611-4619.

Guinney J, Dienstmann R, Wang X, de Reynies A, Schlicker A, Soneson C (2015) The consensus molecular subctypes of colorectal cancer. Nat Med 21(11): 1350-1356.

Gustafsson JK, Ermund A, Ambort D, Johansson ME, Nilsson HE, Thorell K, Hebert H, Sjovall H, Hansson GC (2012) Bicarbonate and functional CFTR channel are required for proper mucin secretion and link cystic fibrosis with its mucus phenotype. J Exp Med 209(7): 1263-1272.

Haller DG, Tabernero J, Maroun J, de Braud F, Price T, Van Cutsem E, Hill M, Gilberg F, Rittweger K, Schmoll HJ (2011) Capecitabine plus oxaliplatin compared with fluorouracil and folinic acid as adjuvant therapy for stage III colon cancer. J Clin Oncol 29(11): 1465-1471.

Kennedy RD, Bylesjo M, Kerr P, Davison T, Black JM, Kay EW, Holt RJ, Proutski V, Ahdesmaki M, Farztdinov V, Goffard N, Hey P, McDyer F, Mulligan K, Mussen J, O’Brien E, Oliver G, Walker SM, Mulligan JM, Wilson C, Winter A, O'Donoghue D, Mulcahy H, O'Sullivan J, Sheahan K, Hyland J, Dhir R, Bathe OF, Winqvist O, Manne U, Shanmugam C, Ramaswamy S, Leon EJ, Smith Jr. WI, McDermott U, Wilson RH, Longley D, Marshall J, Cummins R, Sargent DJ, Johnston PG, Harkin DP (2011) Development and independent validation of a prognostic assay for stage II colon cancer using formalin-fixed paraffin-embedded tissue. J Clin Oncol 29(35): 4620-4626.

Kim JH, Rhee YY, Bae JM, Kwon HJ, Cho NY, Kim MJ, Kang GH (2013) Subsets of microsatellite-unstable colorectal cancers exhibit discordance between the CpG island methylator phenotype and MLH1 methylation status. Mod Pathol 26(7): 1013-1022.

Kopetz S, Tabernero J, Rosenberg R, Jiang ZQ, Moreno V, Bachleitner-Hofmann T, Lanza G, Stork-Sloots L, Maru D, Simon I, Capella G, Salazar R (2015) Genomic classifier ColoPrint predicts recurrence in stage II colorectal cancer patients more accurately than clinical factors. Oncologist 20(2): 127-133.

Lehen'kyi V, Shapovalov G, Skryma R, Prevarskaya N (2011) Ion channnels and transporters in cancer. 5. Ion channels in control of cancer and cell apoptosis. Am J Physiol Cell Physiol 301(6): C1281-C1289.

Lenos K, Goos JA, Vuist IM, den Uil SH, Delis-van Diemen PM, Belt EJ, Stockmann HB, Bril H, de Wit M, Carvalho B, Gilblett S, Pritchard CA, Meijer GA, van Kooyk Y, Fijneman RJ, van Vliet SJ (2015) MGL Ligand expression is correlated to BRAF mutation and associated with poor survival of stage III colon cancer patients. Oncotarget 6(28): 26278-26290.

Maak M, Simon I, Nitsche U, Roepman P, Snel M, Glas AM, Schuster T, Keller G, Zeestraten E, Goossens I, Janssen KP, Friess H, Rosenberg R (2013) Independent validation of a prognostic genomic signature (ColoPrint) for patients with stage II colon cancer. Ann Surg 257(6): 1053-1058.

March HN, Rust AG, Wright NA, ten HJ, de RJ, Eldridge M, van der Weyden L, Berns A, Gadiot J, Uren A, Kemp R, Arends MJ, Wessels LF, Winton DJ, Adams DJ (2011) Insertional mutagenesis identifies multiple networks of cooperating genes driving intestinal tumorigenesis. Nat Genet 43(12): 1202-1209.

Marisa L, de RA, Duval A, Selves J, Gaub MP, Vescovo L, Etienne-Grimaldi MC, Schiappa R, Guenot D, Ayadi M, Kirzin S, Chazal M, Flejou JF, Benchimol D, Berger A, Lagarde A, Pencreach E, Piard F, Elias D, Parc Y, Olschwang S, Milano G, Laurent-Puig P, Boige V (2013) Gene expression classification of colon cancer into molecular subtypes: characterization, validation, and prognostic value. PLoS Med 10(5): e1001453.

Moertel CG, Fleming TR, MacDondald JS, Haller DG, Laurie JA, Goodman PJ, Ungerleider JS, Emerson WA, Tormey DC, Glick JH et al. (1990) Levamisole and fluorouracil for adjuvant therapy of resected colon carcinoma. N Engl J Med 322(6): 352-358.
O'Connell JB, Maggard MA, Ko CY (2004) Colon cancer survival rates with the new American Joint Committee on Cancer sixth edition staging. J Natl Cancer Inst 96(19): 1420-1425.

Park JH, Kim MJ, Park SC, Kim MJ, Hong CW, Sohn DK, Han KS, Oh JH (2015) Difference in time to locoregional recurrence between patients with right-sided and left-sided colon cancers. Dis Colon Rectum 58(9): 831-837.

Pedersen SF, Hoffmann EK, Novak I (2013) Cell volume regulation in epithelial physiology and cancer. Front Physiol 4.

Peroz D, Rodriguez N, Choveau F, Baro I, Merot J, Loussouarn G (2008) Kv7.1 (KCNQ1) properties and channelopathies. J Physiol 586(7): $1785-1789$.

Roepman P, Schlicker A, Tabernero J, Majewski I, Tian S, Moreno V, Snel MH, Chresta CM, Rosenberg R, Nitsche U, Macarulla T, Capella G, Salazar R, Orphanides G, Wessels LF, Bernards R, Simon IM (2014) Colorectal cancer intrinsic subtypes predict chemotherapy benefit, deficient mismatch repair and epithelial-to-mesenchymal transition. Int J Cancer 134(3): 552-562.

Rotte A, Bhandaru M, Foller M, Biswas R, Mack AF, Friedrich B, Rexhepaj R, Nasir O, Ackermann TF, Boini KM, Kunzelmann K, Behrens J, Lang F (2009) APC sensitive gastric acid secretion. Cell Physiol Biochem 23(1-3): 133-142.

Sadanandam A, Lyssiotis CA, Homicsko K, Collisson EA, Gibb WJ, Wullschleger S, Ostos LCG, Lannon WA, Grotzinger C, Del Rio M, Lhermitte B, Olshen AB, Wiedenmann B, Cantley LC, Gray JW, Hanahan D (2013) A colorectal cancer classification system that associates cellular phenotype and responses to therapy. Nat Med 19(5): 619-625.

Salazar R, Roepman P, Capella G, Moreno V, Simon I, Dreezen C, Lopez-Doriga A, Santos C, Marijnen C, Westerga J, Bruin S, Kerr D, Kuppen P, van d V, Morreau H, Van VL, Glas AM, Van't Veer LJ, Tollenaar R (2011) Gene expression signature to improve prognosis prediction of stage II and III colorectal cancer. J Clin Oncol 29(1): 17-24.

Sansom OJ, Reed KR, Hayes AJ, Ireland H, Brinkmann H, Newton IP, Batlle E, Simon-Assmann P, Clevers H, Nathke IS, Clarke AR, Winton DJ (2004) Loss of Apc in vivo immediately perturbs Wnt signaling, differentiation, and migration. Genes Dev 18(12): 1385-1390.

Schlicker A, Beran G, Chresta CM, McWalter G, Pritchard A, Weston S, Runswick S, Davenport S, Heathcote K, Castro DA, Orphanides G, French T, Wessels LF (2012) Subtypes of primary colorectal tumors correlate with response to targeted treatment in colorectal cell lines. $B M C$ Med Genomics 5: 66.

Silva AL, Dawson SN, Arends MJ, Guttula K, Hall N, Cameron EA, Huang TH, Brenton JD, Tavare S, Bienz M, Ibrahim AE (2014) Boosting Wnt activity during colorectal cancer progression through selective hypermethylation of Wnt signaling antagonists. BMC Cancer 14: 891.

Sinicrope FA, Rego RL, Halling KC, Foster N, Sargent DJ, La Plant B, French AJ, Laurie JA, Goldberg RM, Thibodeau SN, Witzig TE (2006) Prognostic impact of microsatellite instability and DNA ploidy in human colon carcinoma patients. Gastroenterology 131(3): 729-737.

Sinicrope FA, Sargent DJ (2012) Molecular pathways: microsatellite instability in colorectal cancer: prognostic, predictive and therapeutic implications. Clin Cancer Res 18(6): 1506-1512.

Starr TK, Allaei R, Silverstein KA, Staggs RA, Sarver AL, Bergemann TL, Gupta M, O'Sullivan MG, Matise I, Dupuy AJ, Collier LS, Powers S, Oberg AL, Asmann YW, Thibodeau SN, Tessarollo L, Copeland NG, Jenkins NA, Cormier RT, Largaespada DA (2009) A transposon-based genetic screen in mice identifies genes altered in colorectal cancer. Science 323(5922): 1747-1750.

Takeda H, Wei Z, Koso H, Rust AG, Yew CC, Mann MB, Ward JM, Adams DJ, Copeland NG, Jenkins NA (2015) Transposon mutagenesis identifies genes and evolutionary forces driving gastrointestinal tract tumor progression. Nat Genet 47(2): 142-150.

Than BL, Goos JA, Sarver AL, O'Sullivan MG, Rod A, Starr TK, Fijneman RJ, Meijer GA, Zhao L, Zhang Y, Largaespada DA, Scott PM, Cormier RT (2014) The role of KCNQ1 in mouse and human gastrointestinal cancers. Oncogene 33(29): 3861-3868.

Than BL, Linnekamp JF, Starr TK, Largaespada DA, Rod A, Zhang Y, Bruner V, Abrahante J, Schumann A, Luczak T, Niemczyk A, O'Sullivan MG, Medema JP, Fijneman RJ, Meijer GA, van den Broek E, Hodges CA, Scot PM, Vermeulen L, Cormier RT (2016) CFTR is a tumor suppressor gene in murine and human intestinal cancer. Oncogene 35(32): 4179-4187.

The Code for Proper Secondary Use of Human Tissue (2011) Available at https://www.federa.org/codes-conduct. 
Venook AP, Niedzwiecki D, Lopatin M, Ye X, Lee M, Friedman PN, Frankel W, Clark-Langone K, Millward C, Shak S, Goldberg RM, Mahmoud NN, Warren RS, Schilsky RL, Bertagnolli MM (2013) Biologic determinants of tumor recurrence in stage II colon cancer: validation study of the 12-gene recurrence score in cancer and leukemia group B (CALGB) 9581. J Clin Oncol 31(14): 1775-1781.

Vilar E, Gruber SB (2010) Microsatellite instability in colorectal cancer-the stable evidence. Nat Rev Clin Oncol 7(3): 153-162.

Weisenberger DJ, Siegmund KD, Campan M, Young J, Long TI, Faasse MA, Kang GH, Widschwendter M, Weener D, Buchanan D, Koh H, Simms L, Barker M, Leggett B, Levine J, Kim M, French AJ, Thibodeau SN, Jass J, Haile R, Laird PW (2006) CpG island methylator phenotype underlies sporadic microsatellite instsability and is tightly associated with BRAF mutation in colorectal cancer. Nat Genet 38(7): 787-793.

Wilmes J, Haddad-Tovolli R, Alesutan I, Munoz C, Sopjani M, Pelzl L, Bogatikov E, Fedele G, Faggio C, Seebohm G, Foller M, Lang F (2012) Regulation of KCNQ1/KCNE1 by beta-catenin. Mol Membr Biol 29(3-4): 87-94.

Yang K, Popova NV, Yang WC, Lozonschi I, Tadesse S, Kent S, Bancroft L, Matise I, Cormier RT, Scherer SJ, Edelmann W, Lipkin M, Augenlicht L,
Velcich A (2008) Interaction of Muc2 and APC on Wnt signaling and in intestinal tumorigenesis: potential role of chronic inflammation. Cancer Res 68(18): 7313-7322.

Yothers G, O'Connel MJ, Allegra CJ, Kuebler JP, Colangelo LH, Petrelli NJ, Wolmark N (2011) Oxaliplatin as adjuvant therapy for colon cancer: update results of NSABP C-07 trial, including survival and subset analyses. J Clin Oncol 29(28): 3768-3774.

Yothers G, O'Connell MJ, Lee M, Lopatin M, Clark-Langone KM, Millward C, Paik S, Sharif S, Shak S, Wolmark N (2013) Validation of the 12-gene colon cancer recurrence score in NSABP C-07 as a predictor of recurrence in patients with stage II and III colon cancer treated with fluorouracil and leucovorin (FU/LV) and FU/LV plus oxaliplatin. J Clin Oncol 31(36): 4512-4519.

This work is published under the standard license to publish agreement. After 12 months the work will become freely available and the license terms will switch to a Creative Commons AttributionNonCommercial-Share Alike 4.0 Unported License. 